\title{
Nordic research on special needs education in upper secondary vocational education and training: A review
}

\section{Camilla Björk-Åman ${ }^{1}$, Robert Holmgren², Gerd Pettersson ${ }^{2}$ \& Kristina Ström ${ }^{1}$}

\author{
1Åbo Akademi University, Finland \& 2Umeå University, Sweden \\ (robert.holmgren@umu.se)
}

\begin{abstract}
The purpose of this article is to describe and analyse the state of the art of research on special needs education (SNE) in the context of the Nordic countries' vocational education and training (VET) systems during the period January 2010 to September 2018. Twenty studies remained after the search procedure and thematic analysis, 15 of which deal with the practice level and five with the organisation level. No studies were identified as belonging to the policy level. The following themes were found at the practice level: teachers' work and role, teaching and learning, student transition and student dropout. Themes identified at the organisation level were changes to vocational policy documents and educational practices, and school organisation and its implementation. Finland dominates in terms of number of studies. Furthermore, the review shows that there were few studies in the area of SNE in VET. The results show that further studies are needed to acquire more knowledge about SNE in vocational education.
\end{abstract}

Keywords: special needs education (SNE), special educational needs (SEN), upper secondary education, vocational education and training (VET) 


\section{Introduction}

The Nordic countries, Denmark, Finland, Iceland, Norway, and Sweden are widely known for educational policies, which promote equal and accessible education for all. Another characteristic of the policies is the ambition to combine social welfare and equality with high economic growth (Michelsen \& Stenström, 2018). However, economic growth requires a workforce with vocational skills vital to society. The vocational education and training system (VET), located at the intersection between the educational system and the labour market, has a key role in educating and training young people who do not opt for higher education and in providing key skills for all sectors of the labour market (Helms Jørgensen, 2018; Helms Jørgensen et al., 2019). Nevertheless, the Nordic VET systems are balancing between being a part of a school for all, characterised by egalitarian and inclusive values, and providing the labour market with skilled workers (Lundahl, 2016). These goals may seem contradictory, but Helms Jørgensen (2018) points out that VET has the double responsibility of educating a skilled labour force and supporting disadvantaged young people and learners who encounter barriers to learning, in other words, learners with special educational needs (SEN). SEN policies are important in this respect when it comes to creating an inclusive learning environment that empowers learners to reach their highest possible potential enabling them to secure employability and better lives (Cedefop, 2015). Therefore, VET education providers, school management teams and teachers have a great responsibility to ensure that teaching and learning environments are suited to all students, regardless of whether they need extra support, temporarily, or over an extended period. For the individual student, adequate support is crucial. Fischbein and Österberg (2003) argue that if students do not receive appropriate support, the risk is high that they will have frequent experiences of failure, which, in the long run, can affect their self-esteem and future plans negatively. This assumption brings special needs education within VET to the fore. In the present review, we attempt to shed light on how special needs education is depicted in Nordic VET research.

The concept of special needs education (SNE) has evolved during the last few decades. Having had a disability focus, the definition of SNE has been broadened and now includes a wide variety of student diversity and educational needs (Kiuppis \& Haustätter, 2014). For the purpose of this article, SNE is conceptualised as a system of special educational practices and support measures that promote learning, social inclusion and quality of life for young people who, for various reasons, encounter, or are at risk of encountering, disabling difficulties or obstacles in their studies (Tangen, 2012). The basic idea behind SNE within VET is to support young people in attaining their educational and social goals (Hirvonen et al., 2009). This is possible by providing individualised support and creating favourable and accessible learning environments. 
However, keeping in mind the challenges regarding the development of adequate support systems that Nordic VET is facing, we believe that it is important to map existing studies related to SNE in Nordic VET research. It should also be mentioned that previous research on SNE seems to be mainly focused on the primary school (Pettersson, 2017)). Research findings have the potential to inform practice and contribute to a deeper understanding of the diverse educational needs of VET students. We also agree with Ahlberg (2009) on the fruitfulness of combining previously unrelated knowledge and study objects (SNE and VET). Such fusions can, according to Ahlberg, have a strong potential to develop practice as well as theory in the field.

The purpose of this systematic literature review is to describe and analyse Nordic research on SNE in the context of the Nordic countries' vocational education and training (VET) systems published between January 2010 and September 2018. The research questions are: What themes are central to current Nordic research on special education in vocational education? What differences and similarities can be identified between the Nordic countries in terms of quantity and content within this field of research?

In order to contextualise the review, we start by providing a short overview of the Nordic countries' vocational education systems at the upper secondary level. The time period chosen is interesting, as it was a period of structural changes in VET in the Nordic countries (Helms Jørgensen, 2018), something that researchers may have been interested in studying from an SNE perspective as well.

\section{Upper secondary vocational education in the Nordic countries: \\ A brief description}

The educational goals of VET in the Nordic countries are essentially the same, namely to prepare students for participation in the labour market, to support lifelong learning and to encourage creativity, innovation and entrepreneurship (Pereira et al., 2016). However, the structures of the Nordic education systems differ. While Finland and Norway have a parallel system with separate general and vocational upper secondary education, Sweden, Denmark, and Iceland have a cohesive upper secondary education where schools usually offer both general and vocational programmes. The key characteristics of the VET systems in the Nordic countries are presented in Table 1 (Cedefop, 2010; Cedefop Dk, 2012; Finnish National Agency for Education [EDUFI], 2018a, 2018b; Government of Iceland, 2019; Ministry of Education and Culture [OKM] \& EDUFI, 2018; Ministry of Children and Education, Denmark, 2010, 2019a, 2019c; Námsmatsstofnun, 2014; Statistics Iceland, 2016; Statistics Norway, 2018; Studyinfo, 2019; Swedish National Agency for Education, 2018; Utdanningsdirektoratet, 2018; Vilbli.no, 2019). 
Camilla Björk-Åman, Robert Holmgren, Gerd Pettersson \& Kristina Ström

Table 1. Key characteristics of the Nordic VET systems.

\begin{tabular}{|c|c|c|c|c|c|}
\hline Country & $\begin{array}{l}\text { Number of } \\
\text { VET pro- } \\
\text { grammes }\end{array}$ & $\begin{array}{l}\text { Duration of } \\
\text { programme }\end{array}$ & $\begin{array}{l}\text { School-based } \\
\text { learning vs } \\
\text { workplace- } \\
\text { based } \\
\text { learning (\%) }\end{array}$ & $\begin{array}{l}\text { VET students as } \\
\text { a percentage of } \\
\text { all students in } \\
\text { upper secondary } \\
\text { education }\end{array}$ & $\begin{array}{l}\text { Percentage } \\
\text { of students } \\
\text { graduating }\end{array}$ \\
\hline Denmark & $\begin{array}{l}\text { Appren- } \\
\text { ticeship: } 12 \\
\text { entryways }\end{array}$ & 3-4 years & $\begin{array}{l}\text { Apprenticeship } \\
35-50 \% \text { vs } \\
50-65 \%\end{array}$ & $\begin{array}{l}\text { VET programmes } \\
\text { and Apprentice- } \\
\text { ship, in total: } 48 \%\end{array}$ & $52 \%$ \\
\hline Finland & $\begin{array}{l}10 \text { different } \\
\text { fields of } \\
\text { education }\end{array}$ & $\begin{array}{l}\text { Individual } \\
\text { study time, } \\
\text { usually } \\
\text { around } \\
\text { three years }\end{array}$ & $\begin{array}{l}\text { Student- } \\
\text { individual } \\
\text { solutions }\end{array}$ & $\begin{array}{l}\text { VET programmes } \\
52 \% \\
\text { Apprenticeship } \\
2 \%\end{array}$ & $\begin{array}{l}76 \% \text { in } \\
\text { school- } \\
\text { based edu- } \\
\text { cation, after } \\
5 \text { years }\end{array}$ \\
\hline Iceland & $\begin{array}{l}>100 \text { VET } \\
\text { pro- } \\
\text { grammes }\end{array}$ & 3-4 years & $\begin{array}{l}\text { Different solu- } \\
\text { tions in differ- } \\
\text { ent vocations, } \\
2-4 \text { years }\end{array}$ & $\begin{array}{l}\text { VET programmes } \\
31 \%\end{array}$ & $\begin{array}{l}45 \% \text { after } \\
6 \text { years }\end{array}$ \\
\hline Norway & $\begin{array}{l}8 \text { VET pro- } \\
\text { grammes }\end{array}$ & 4 years & $50 \%$ vs $50 \%$ & $\begin{array}{l}\text { VET programmes } \\
37 \% \\
\text { Apprenticeship } \\
21 \%\end{array}$ & $\begin{array}{l}60 \% \text { after } \\
5 \text { years }\end{array}$ \\
\hline Sweden & $\begin{array}{l}12 \text { VET } \\
\text { pro- } \\
\text { grammes } \\
\text { School- } \\
\text { based or } \\
\text { Appren- } \\
\text { ticeship }\end{array}$ & 3 years & $\begin{array}{l}\text { VET pro- } \\
\text { grammes } \\
87 \% \text { vs } 13 \% \\
\text { Apprenticeship } \\
50 \% \text { vs } 50 \%\end{array}$ & $\begin{array}{l}\text { VET programmes } \\
28 \% \\
\text { Apprenticeship } \\
3 \%\end{array}$ & $\begin{array}{l}72 \% \text { after } \\
3 \text { years }\end{array}$ \\
\hline
\end{tabular}

As shown in Table 1, in Denmark, VET is designed as an apprenticeship education where education contracts are established between students and companies. The apprenticeship begins with a basic school-based education, which is followed by workplace-based training. The other countries offer both a schoolbased and an apprenticeship-based education, with the former one dominating. The duration of the workplace-based learning in VET varies greatly between apprenticeship education (50-65\%) and school-based training (35-50\%). While the duration of the VET education is quite similar in the Nordic countries, 3-4 years, there are noticeable differences with regard to the proportion of VET students who graduate. In Finland and Norway, more than half of all upper secondary 
school students are studying on a vocational programme, which can be compared with Denmark, Iceland and Sweden, where the corresponding proportion is less than one third. The proportion of VET students who graduate within 3-6 years after their studies on the programmes, varies from $45 \%$ in Iceland to $76 \%$ in Finland. Overall, it can be concluded that clear similarities exist between VET in the Nordic countries in terms of the number of programmes and their length, while there is greater variation when it comes to the proportion of workplacebased learning, VET students and VET students who graduate.

\section{Special needs education in VET in the Nordic countries}

Special needs education (SNE) in VET is an integral part of the Nordic countries' upper secondary education systems. As shown in Figure 1, SNE includes several intersecting levels: policy, organisation, and educational practice. The policy level refers to the education system level and comprises the educational goals formulated in the national policy documents of the Nordic countries. The organisation level refers to descriptions of the organisation of educational practices in terms of structures and resources, while the educational practice level includes, for example, teaching and learning environments, learning activities and special adjustments and measures.

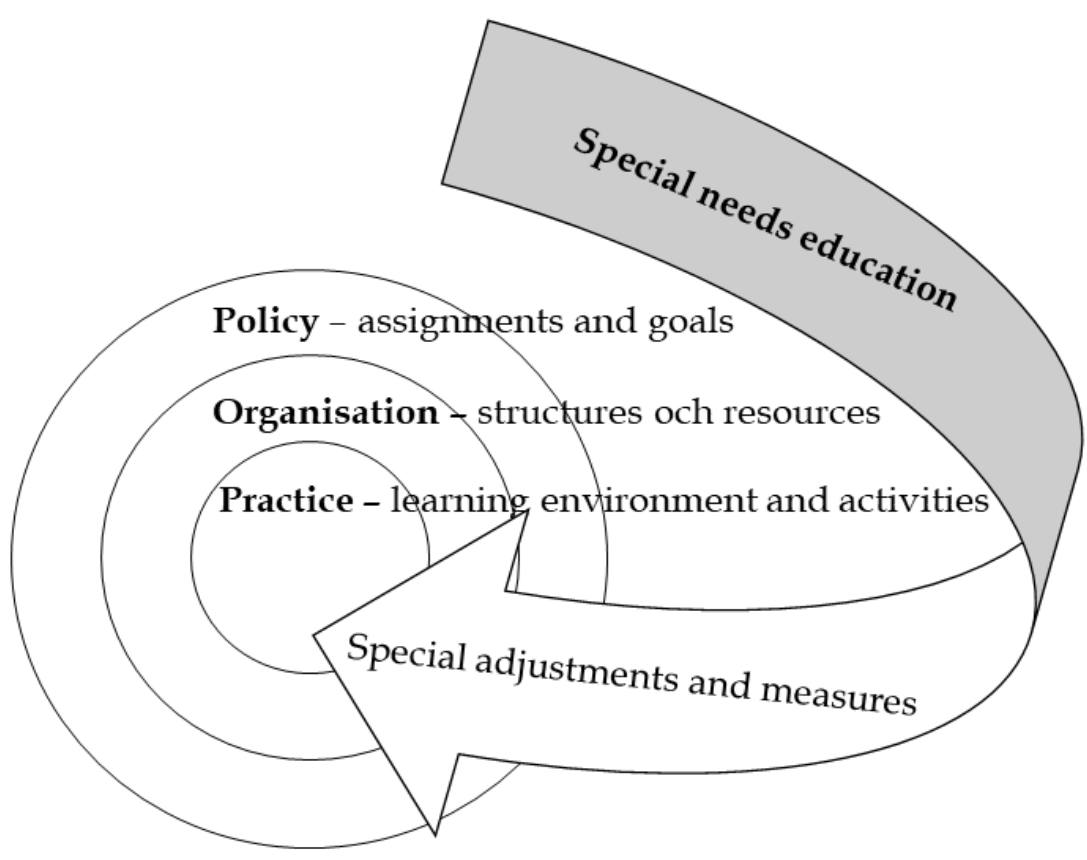

Figure 1. Three levels of special needs education in VET. 
Our review of the Nordic countries' educational policy documents indicates that similarities as well as differences prevail. In the following part, we will briefly describe each country's policies and support systems. In the national policy documents, various terms are used to describe students' learning difficulties. In this section, we use the terms found in the respective policy documents.

According to the Danish education act (Ministry of Children and Education, Denmark, 2019c), the VET programmes should promote the students' well-being, health, development and learning. In other words, in order to support the students' choice of education, their participation and well-being, the learning environment must be adapted regarding the organisation and implementation of the teaching content. The act also states that schools' have an obligation to provide SNE for students with such needs. For example, differentiated forms of teaching should be used that take into account the students' different learning prerequisites. Over the past ten years (2008-2017), VET students' need for SNE has increased, with reading and writing difficulties constituting the main reason (Danish Evaluation Institute [EVA], 2019). The Danish education system also includes an individual compensatory support system (Special Education Support - SPS), whose purpose is to enable students with physical or psychological disabilities to complete their education on equal terms to other students (Ministry of Children and Education, Denmark, 2019b). Evaluations of SPS show that VET students who receive support via this system complete the practical part of the training in school more often (31\%) than VET students without physical or psychological disabilities (13\%). Further comparisons show that $65 \%$ of the SPS students are employed two years after graduation, compared to $81 \%$ of other students (EVA, 2019). Requirements regarding teachers' special needs competence are not specified in the policy documents (Ministry of Children and Education, Denmark, 2019c).

In Finland, the VET reform $(2017 / 2018)$ brought with it two new concepts in SNE: special support and intensive special support (Finnish vocational education and training act, 2017). Special support is intended for 'students who require special help in their studies due to learning disability, illness, delayed development or some other reason' (Finnish vocational education and training act, 2017, 64 §). The definition is wide, and no expert assessments or diagnoses are needed for students to receive support. Special support includes various forms of support, such as special arrangements in the learning environment, various aids, e.g., speech synthesis and easy-to-read material, and extra counselling. It is laid down in the act that there should be staff with special responsibility for coordinating support measures, but all teachers should be involved in supporting the student (Opetushallitus, 2018). There are only a few VET providers that are qualified to offer intensive special support. This kind of special educational support is intended for students with 'severe learning difficulties or disabilities or illness 
which mean that they need more extensive and versatile special support' (Vocational education act, 2017, 65 §) and is provided by special schools and in special classes. Both forms of support are included in the Vocational education act and as long as the studies are vocationally oriented, the same curriculum is used for all students, with the possibility to individualise it for students with severe difficulties. According to the Decree on teacher qualifications (1998/2017), a special education teacher (SET) or special vocational education teacher (SVET) exam is required to be qualified to work as a teacher responsible for the provision of the two support forms. In practice, SETs often support students in general subjects whereas SVETs support students in vocational subjects (Pirttimaa \& Hirvonen, 2016).

According to the Icelandic National curriculum guide for upper secondary schools (Ministry of Education, Science and Culture, Iceland [MoESC], 2011), 'students with disabilities should study together with other students in so far as this is possible' (p. 75). The same inclusive thought is also stated in the Upper secondary education act (2008, Article 34): 'Whenever possible, students with disabilities shall pursue their studies in the same school premises as other students.' The Upper secondary education act (2008, Article 34) stresses that 'appropriate instruction and special pedagogic support shall be provided to students with a disability [...] and to students with emotional or social difficulties.' In addition, 'dyslexic students', 'students with specific learning difficulties or suffering from an illness' and 'hearing impaired and deaf students' are specifically mentioned in the act. In the Curriculum guide (MoESC, 2011), the target group for special education in upper secondary schools is specified in accordance with the Upper secondary education act, but with an addition, namely that the right to special education is 'based on confirmed special needs' (p. 75). In the Icelandic system, the possibility to receive special education is thus based on diagnoses or other kinds of expert documentation of the needs. The support can be provided within the regular study programmes of a VET school or in specific programmes for students with disabilities (MoESC, 2011). According to Eiríksdóttir and Rosvall (2019), students with, for example, intellectual disabilities or learning difficulties often attend VET programmes specially tailored for this category of students, and the education is then provided in special classes. The curriculum guide contains specific mention of the necessity of transfer of information in the transition process between different school levels, but there is no information about what kind of support a student can receive. According to Eiríksdóttir and Rosvall (2019, p. 4), the support may include 'student counselling services, special study halls, and help with writing, test-taking, etc.'

In Norway the policy documents stress so-called adapted education as a first step to meet the various needs of the students in a group, in both basic and further education (Act relating to primary and secondary education and training 
[Education act], 1998). However, adapted education is not about individual solutions but about 'striking a happy balance between each pupil's abilities and capacities and the entire classroom/school community' (Norwegian Ministry of Education and Research, 2011, p. 6). If the adaptive education is not enough to meet the needs of a student, the Education act states that students who have difficulty benefiting from the regular teaching offered are entitled to special education (Education act, 1998). The target group for special education is thus initially widely defined in the act. However, the act later specifies who is actually entitled to special education. For a student to be granted special education, an expert assessment from the PP-service (pedagogical-psychological-service) is required. In the assessment, the special needs of the student are described, and appropriate support suggested. The school then makes a decision about the special education for the student based on the assessment, and an individual training plan is drawn up (Education act, 1998; Utdanningsdirektoratet, 2017). Special education activities may be, for example, setting learning goals for a student other than those of the rest of the group, follow-up of the student in class by a teacher or assistant or the use of special learning aids (Foreldreutvalget for grunnopplæringen, 2018).

In Sweden, the Swedish education act (2010) states that all students have the right to education and development, which means that students must be given the opportunity to reach established knowledge goals to the extent possible and that schools should promote the development of all students through positive and equal learning environments. In addition, the national curriculum for upper secondary schools (Swedish National Agency for Education, 2011) states that the teaching must be adapted to each student's prerequisites and needs. The Swedish National Agency for Education (2014) makes a distinction between extra adjustments and special needs support. Extra adjustments constitute the initial measure that should be taken to support a student and should preferably be provided by the vocational teachers in the vocational subjects. Examples of extra adjustments include teachers' organisation of the learning environment and the use of pedagogical tools and teaching methods adapted to the students' needs. If these adjustments are not considered sufficient, the head teacher has the responsibility to investigate and document the student's need for a special support and action plan describing measures to be taken with a view to supporting the student's learning and development (Swedish National Agency for Education, 2014). Furthermore, it is stated that schools should have a teacher with special educational competence who has consulting and supervisory duties (cf. Swedish education act, 2010; Swedish National Agency for Education, 2014). It is also stated that special education consultations for teachers is a key activity. However, due to the fact that there are few full-time positions for special education teachers in the upper secondary school $(<3 \%$ of all full-time teaching positions), vocational teachers have limited access to such consultations (Swedish National Agency for Education, 2018). 
Nordic research on special needs education in upper secondary VET

Table 2. Special education support in VET in the Nordic countries.

\begin{tabular}{|c|c|c|c|c|c|c|}
\hline Country & $\begin{array}{l}\text { Availability of } \\
\text { special educa- } \\
\text { tional support } \\
\text { within the } \\
\text { regular system }\end{array}$ & $\begin{array}{l}\text { Existence } \\
\text { of segre- } \\
\text { gated so- } \\
\text { lutions }\end{array}$ & $\begin{array}{l}\text { Target } \\
\text { group } \\
\text { defined }\end{array}$ & $\begin{array}{l}\text { Eligibil- } \\
\text { ity for } \\
\text { support } \\
\text { through } \\
\text { medical } \\
\text { and/or } \\
\text { psycho- } \\
\text { logical } \\
\text { assess- } \\
\text { ment }\end{array}$ & $\begin{array}{l}\text { Forms of support } \\
\text { mentioned }\end{array}$ & $\begin{array}{l}\text { Specified } \\
\text { qualifica- } \\
\text { tion crite- } \\
\text { ria for } \\
\text { teachers } \\
\text { working } \\
\text { with SEN }\end{array}$ \\
\hline Denmark & $\begin{array}{l}\text { Yes, for indi- } \\
\text { vidual stu- } \\
\text { dents who } \\
\text { have applied } \\
\text { for SPS }\end{array}$ & No & Yes & Yes & $\begin{array}{l}\text { Yes, adaptations in } \\
\text { the learning envi- } \\
\text { ronment and an in- } \\
\text { dividual compensa- } \\
\text { tory support system } \\
\text { (SPS) }\end{array}$ & No \\
\hline Finland & $\begin{array}{l}\text { Yes, a two- } \\
\text { tiered system; } \\
\text { special sup- } \\
\text { port and inten- } \\
\text { sive special } \\
\text { support }\end{array}$ & Yes & $\begin{array}{l}\text { Yes, but } \\
\text { no disa- } \\
\text { bility cat- } \\
\text { egories } \\
\text { are men- } \\
\text { tioned }\end{array}$ & No & $\begin{array}{l}\text { Yes, for instance ad- } \\
\text { justments in the } \\
\text { learning environ- } \\
\text { ment, learning aids } \\
\text { and counselling }\end{array}$ & Yes \\
\hline Iceland & $\begin{array}{l}\text { Yes, for stu- } \\
\text { dents with } \\
\text { confirmed spe- } \\
\text { cial needs }\end{array}$ & Yes & Yes & Yes & $\begin{array}{l}\text { Yes, for instance } \\
\text { study support and } \\
\text { counselling }\end{array}$ & No \\
\hline Norway & $\begin{array}{l}\text { Yes, adapted } \\
\text { education for } \\
\text { all and special } \\
\text { education for } \\
\text { those who } \\
\text { have a right to } \\
\text { such education }\end{array}$ & No & $\begin{array}{l}\text { Yes, but } \\
\text { no disa- } \\
\text { bility cat- } \\
\text { egories } \\
\text { are men- } \\
\text { tioned }\end{array}$ & $\begin{array}{l}\text { Yes, for } \\
\text { special } \\
\text { education }\end{array}$ & $\begin{array}{l}\text { Yes, for instance in- } \\
\text { dividual learning } \\
\text { goals and learning } \\
\text { aids }\end{array}$ & No \\
\hline Sweden & $\begin{array}{l}\text { Yes, a two- } \\
\text { tiered system; } \\
\text { extra adjust- } \\
\text { ments and spe- } \\
\text { cial support }\end{array}$ & $\begin{array}{l}\text { No, not } \\
\text { within } \\
\text { regular } \\
\text { system }\end{array}$ & No & $\begin{array}{l}\text { Yes, for } \\
\text { special } \\
\text { support }\end{array}$ & $\begin{array}{l}\text { Yes, adaptations in } \\
\text { the learning envi- } \\
\text { ronment and teach- } \\
\text { ing methods }\end{array}$ & $\begin{array}{l}\text { No, but } \\
\text { each school } \\
\text { should } \\
\text { have a } \\
\text { teacher } \\
\text { with spe- } \\
\text { cial educa- } \\
\text { tional com- } \\
\text { petence }\end{array}$ \\
\hline
\end{tabular}


As shown in Table 2, there are similarities as well as differences between the Nordic countries' policy documents regarding special education support. All five countries have some kind of support system for students with SEN, ranging from an individualised support system (Denmark) to school-based support systems for all students who need or are entitled to support. Most Nordic countries require some kind of assessment or expert opinion in order to offer (special) support within the special education system. The exception is Finland, which seems to have the most inclusive support system. No formal diagnoses or statements are needed. Finland is also the exception when it comes to qualification criteria for teachers working with SEN students. Differences between countries are also noted with respect to segregated solutions and target group definitions. These differences are related to different traditions and priorities, but they may affect, on the one hand the institutions' possibilities to provide support and on the other individual students' possibilities to complete their vocational education and access the labour market.

\section{Methods}

A systematic search was performed in order to find studies focusing on SNE in Nordic VET. The following sections describe the criteria and selection process, the search process, and the final analysis procedure.

\section{Criteria and selection process}

In order to be eligible for inclusion in the review, studies had to meet the following criteria:

1) Their relevance to the research topic and the specific criteria for special needs education, as described earlier in this article, and a focus on the field of vocational education and training in upper secondary education. Consequently, the following categories of studies were excluded: Studies (a) which did not have a specific educational perspective focusing on gender or ethnic diversity, (b) studies dealing with young people at risk of dropout from school for reasons other than special educational ones, such as dropout due to lack of motivation, (c) studies focused primarily on other levels of education such as basic and higher education and (d) studies focusing on specific educational needs, such as learning difficulties or disabilities.

2) Studies had to be peer-reviewed and published between 2010 and 2018.

3) Studies focusing on VET and special needs education in the regular vocational education system in each country were included, due to differences in the Nordic countries' vocational education systems. Thus, studies on intensive special support ('särskilt krävande stöd') in Finnish VET were included, but not 
studies on Swedish upper secondary special schools ('gymnasiesärskolor'), even though, in practice, their activities are quite similar.

4) Although the search process was carried out using English search terms, studies published in the Nordic languages were included if they had an English abstract or summary.

\section{Search process}

Searches were performed between January 2018 and September 2018. The search terms used were vocational education (and training) (VET), upper secondary education in combination with special education(al) needs, special needs education and special education combined with the names of the Nordic countries (Denmark, Finland, Iceland, Norway, Sweden).

Databases used in the search process were Google Scholar, Web of Science, Scopus, Eric, Den danske forskningsdatabase (Denmark) Finna and Helka (Finland), Idun (Norway) Libris and Swepub (Sweden). As a complement to the Islandic search, Netla - Online Journal on Pedagogy, was also included in the search process.

In addition to database searches, eight journals within the field of special education and nine journals on vocational education and training were searched, in order to locate further studies (cf. Appendix 1). Relevant studies were also added based on 'snowballing' and personal knowledge.

Initially, 42 studies were selected on the basis of their titles and abstracts. Following a more thorough scrutiny of these studies, 22 were excluded as they were found not to meet the inclusion criteria. Thus, the final selection comprised 20 studies, all of which were in English, except three that were in Finnish with an English summary.

Scientific studies in the field may have been published after year 2018 but these are not included in this review.

\section{Analysis procedure}

The analysis procedure was inspired by thematic analysis methods (Graneheim \& Lundman, 2004). When the search process was completed, the articles were analysed with respect to content areas, country, category level methodology and method, based on the following questions:

1) What is the content (theme) and what is the category level (practice, organisation or policy)?

2) What methodology and methods are used (design, data collection methods)?

3) What are the main contributions/results? 


\section{Results}

In the following section, the results of the review are presented. Table 3 shows the number of identified studies and their distribution among the Nordic countries and the three category levels. Table 4 presents the classification of the identified studies according to category level and theme. The results section is concluded with a thematic account of the content of the studies.

Table 3. Number of studies 2010-2018 (Sept.) classified according to country and category level.

\begin{tabular}{|l|c|c|c|c|c|c|}
\hline $\begin{array}{l}\text { Category } \\
\text { level }\end{array}$ & Denmark & Finland & Iceland & Norway & Sweden & $\begin{array}{c}\text { Studies } \\
\text { per } \\
\text { category } \\
\text { level }\end{array}$ \\
\hline Practice & & 11 & 1 & 3 & & 15 \\
\hline Organisation & & 2 & & & 3 & 5 \\
\hline Policy & & 13 & 1 & 3 & 3 & 20 \\
\hline $\begin{array}{l}\text { Number of } \\
\text { studies per } \\
\text { country }\end{array}$ & 0 & 13 & & & & 0 \\
\hline
\end{tabular}

As shown in Table 3, the majority of the 20 studies belong to the practice level. Moreover, more than half of these were carried out in Finland.

As reported in Table 4, 15 of the 20 studies were categorised as dealing with research areas belonging to the practice level. The dominant themes in these studies are teachers' work and role in VET (7) and student transition (5). Some studies also cover areas at the organisation level while none was identified as belonging to the policy level. 
Nordic research on special needs education in upper secondary VET

Table 4. Studies (2010-2018 Sept.) classified according to category level and themes.

\begin{tabular}{|c|c|c|c|}
\hline Category level & Theme & Author(s)/Year & $\begin{array}{l}\text { Design } \\
\text { (methodology/theory) }\end{array}$ \\
\hline \multirow[t]{13}{*}{$\begin{array}{l}\text { Practice } \\
(\mathrm{N}=15)\end{array}$} & $\begin{array}{l}\text { Teacher's } \\
\text { work and role } \\
(\mathrm{N}=7)\end{array}$ & $\begin{array}{l}\text { Bell, Hirvonen, Kukemelk, } \\
\text { Pancocha, Vadurova \& Hion } \\
\text { (2014) }\end{array}$ & $\begin{array}{l}\text { Based on previous research and } \\
\text { document analysis }\end{array}$ \\
\hline & & Hirvonen (2011) & $\begin{array}{l}\text { Case study, historical perspec- } \\
\text { tive, contemporary challenges }\end{array}$ \\
\hline & & $\begin{array}{l}\text { Hirvonen (Ed.) (2015a, 2015b, } \\
\text { 2018) }\end{array}$ & $\begin{array}{l}\text { Anthology: different design in } \\
\text { different studies }\end{array}$ \\
\hline & & Pirttimaa \& Hirvonen (2016) & Survey $(\mathrm{N}=120), 10$ interviews \\
\hline & & Björk-Åman (2013) & $\begin{array}{l}\text { Focus group interviews, } 7 \\
\text { schools, discourse theory }\end{array}$ \\
\hline & $\begin{array}{l}\text { Teaching and } \\
\text { learning }(\mathrm{N}=1)\end{array}$ & $\begin{array}{l}\text { Stefansdóttir \& Björnsdóttír } \\
\text { (2016) }\end{array}$ & $\begin{array}{l}6 \text { focus groups interviews ( } \mathrm{N}=22 \\
\text { students; } \mathrm{N}=14 \text { teachers), con- } \\
\text { tent analysis }\end{array}$ \\
\hline & $\begin{array}{l}\text { Students with } \\
\text { SEN; transi- } \\
\text { tion }(N=5)\end{array}$ & $\begin{array}{l}\text { Hermanoff, Määttä \& Uusiautti } \\
\text { (2017) }\end{array}$ & $\begin{array}{l}14 \text { interviews, students and par- } \\
\text { ents, narratives }\end{array}$ \\
\hline & & Niemi \& Kurki (2014) & 16 interviews, observations \\
\hline & & $\begin{array}{l}\text { Kirjavainen, Pulkkinen \& } \\
\text { Jahnukainen (2016) }\end{array}$ & Quantitative data \\
\hline & & Myklebust (2013) & Test $(\mathrm{N}=203)$ \\
\hline & & Kvalsund \& Bele (2010) & $\begin{array}{l}\text { Survey }(\mathrm{N}=500) \text {, longitudinal } \\
\text { study }\end{array}$ \\
\hline & $\begin{array}{l}\text { Students with } \\
\text { SEN; drop-out } \\
(\mathrm{N}=2)\end{array}$ & $\begin{array}{l}\text { Hakkarainen, Holopainen \& } \\
\text { Savolainen (2015) }\end{array}$ & Survey $(\mathrm{N}=595)$, test \\
\hline & & Pijl, Frostad \& Mjaavatn (2014) & Survey $(\mathrm{N}=1873+132)$ \\
\hline \multirow[t]{3}{*}{$\begin{array}{l}\text { Organisation } \\
(\mathrm{N}=5)\end{array}$} & $\begin{array}{l}\text { Changes: vo- } \\
\text { cational policy } \\
\text { documents, } \\
\text { educational } \\
\text { practices } \\
(\mathrm{N}=2)\end{array}$ & Hirvonen (2012) & $\begin{array}{l}\text { Case study: Content analysis, } \\
\text { policy documents, historical } \\
\text { perspective; interviews, contem- } \\
\text { porary local analysis, activity } \\
\text { theory }\end{array}$ \\
\hline & & Hakala (2010) & Ethnographic data, interviews \\
\hline & $\begin{array}{l}\text { School organi- } \\
\text { sation and its } \\
\text { implementa- } \\
\text { tion } \\
(\mathrm{N}=3)\end{array}$ & Ramberg $(2013,2016,2017)$ & $\begin{array}{l}\text { Total population surveys, upper } \\
\text { secondary school }\end{array}$ \\
\hline Policy $(\mathrm{N}=0)$ & & & \\
\hline
\end{tabular}

The following section provides thematic descriptions of the content of the studies. 


\section{Practice}

Four themes were identified at the practice level. The first one, presented below, relates to the work and role of teachers in VET seen from a SNE perspective, the second, with only one study, to SEN students' teaching and learning and the third and fourth to two different aspects concerning VET-students with SEN student transition and dropout.

\section{Teachers' work and role in VET}

The role of special education teachers (SETs) and special vocational education teachers (SVETs) is investigated in several of the Finnish studies (Bell et al., 2014; Hirvonen, 2011, 2015a, 2015b, 2018; Pirttimaa \& Hirvonen, 2016). Common features in these studies are descriptions of the need for a development/redefinition of the role of SETs and SVETs from a student-teaching oriented role to a more versatile one where multi-professional cooperation, counselling and promotion of inclusive solutions are stressed. Pirttimaa and Hirvonen (2016) discuss the need to develop special education in VET into something other than a replica of special education in basic education, pointing out that the purpose of VET is to offer students the possibility to learn a vocation. The role of SETs and SVETs is also dealt with in three publications edited by Hirvonen (2015a, 2015b, 2018). In these publications, different aspects of the key components in the development in Finnish VET are discussed from a special educational perspective, for example, competence-based education, learning environments, individualisation, young people and adults studying together in vocational education, digitalisation, multi-professional cooperation, different kinds of local models for implementation of the policy documents and special support. The impact of the changes to the work and roles of SETs and SVETs are problematised and discussed.

In a dissertation by Björk-Åman (2013), the focus is on vocational teachers and general teachers working in VET. Björk-Åman studies the teachers' views on inclusive education from a special educational perspective, focusing on discourses and the teachers' descriptions of the national teaching requirements and versions of students in need of special support. The author stresses that for VET to be inclusive, a holistic approach to the national teaching requirements is needed, based on both vocational skills and the personal development of the student.

\section{Teaching and learning}

Teaching and learning in VET as a part of higher education for students with intellectual disabilities was studied in a research project at the University of Iceland (Stefánsdóttir \& Björnsdóttir, 2016). In this study, courses at the undergraduate level were offered to both disabled and non-disabled students at the School of Education and both teachers and students were interviewed. The goal of the project was, among other things, to collect data on how the students were supported academically and socially by the university lecturers. The results show 
that the university lecturers were initially skeptical, as they feared that the education level might be lowered, and uncertain about what teaching methods to use. However, the students' experiences were overall positive and they thought the education had bolstered their self-esteem, promoted inclusion and increased their opportunities to find employment.

\section{Students with SEN - transition}

The vulnerability of students with SEN is described in studies focusing on the transition into VET, the risk of dropout from vocational education and life after the vocational education and training.

The area of transition into VET is investigated in three Finnish studies. Hermanoff et al. (2017) take a qualitative perspective on the transition process from basic to vocational education, focusing on the student perspective. According to the results of this study, a successful vocational education for the target group, students with intellectual disability, is the sum of many factors depending on the student, the school context, the curriculum and the teachers. In addition, support from the parents is extremely important. The study also shows that the educational choices for students with intellectual disabilities are limited and in need of development. Similar results can be found in a study by Niemi and Kurki (2014) focused on the transition from pre-vocational programmes for students in need of support to vocational education. Niemi and Kurki point out that students with SEN do not have equal access to education, which also affects the counselling they receive. The students' choice of vocational education was negotiated in a counselling process, based on their own plans and hopes but also on the institutional practices and, above all, their restrictions. Kirjavainen et al. (2016) conducted a longitudinal quantitative study based on data from the Official Statistics of Finland. Their results indicate that students with individualised curricula in basic education do not continue to upper secondary education to the same extent as other students; they more often choose a vocational upper secondary education rather than a general upper secondary education and tend to drop out from studies to a greater extent than other students. They also need longer time to complete their studies.

The area of transition after VET is investigated in two studies from Norway that focus on former students with SEN and the time after their upper secondary education. Myklebust (2013) uses a qualitative approach focusing on the risk of becoming dependent on social welfare among former students with SEN, whereas Kvalsund and Bele (2010), in a quantitative, longitudinal study, focus on the effect of school experiences on social relations later on in life. The results are disheartening - for example, former special class students were more likely to be dependent on social welfare and at greater risk of not being a part of social networks and social relations. 
Students with SEN - dropout

Dropout from upper secondary education was investigated from a special educational perspective in two studies, one from Finland and one from Norway. In a longitudinal, quantitative study, Hakkarainen et al. (2015) noted the vulnerable position of students with academic learning difficulties (measured in Year 9; word reading and mathematics) in upper secondary education. Even though the students received educational support, especially at the beginning of their studies, this was not enough to prevent dropout, as evidenced by the fact that $43 \%$ of all students dropping out from upper secondary education (both general and vocational) had academic learning difficulties. The authors concluded that 'other kinds of support besides educational support are needed for those with academic difficulties, and also for other students' (Hakkarainen et al., 2015, p. 417). In a quantitative study conducted in Norway, Pijl et al. (2014) focus on how social relations with parents, teachers, and peers influence SEN students' decisions to stay in or leave upper secondary education. According to this study, support from peers is a key factor for all students for being motivated to stay in school. For students with SEN, however, teacher support is important, especially at the beginning of the studies. Over time, support from teachers becomes less important as they become more dependent on support from peers.

To sum up, young people in need of special educational support seem to be at greater risk than their peers of exclusion from education and society in the transition into vocational education, during their studies, and even as adults, after their upper secondary education.

\section{Organisation}

Two themes were identified at this level. The first of these refers to analyses of how system level changes relate to educational practices regarding SNE and the second to upper secondary schools' organisation of, and ability to implement, SNE.

Changes: Vocational policy documents, educational practices

Hirvonen's (2012) systemic description of Finnish vocational special education over time (1910-2003) reveals a close connection between special needs education and the overall educational structures that prevail at a certain period of time. In her study, Hirvonen brings forth the development from a segregated SNE to more flexible solutions as well as a broader categorisation of needs. One conclusion is that the current pedagogical solutions in vocational education must be supplemented with extended support structures and that the vocational teachers' special educational knowledge needs to be developed. In an ethnographic study by Hakala (2010), tensions are revealed between Finnish political ambitions and practice. For example, Hakala also describes the enlargement of the target 
group at vocational special schools (since 2018, students requiring intensive special support), as, in addition to students with intellectual disabilities, it now also includes students with various learning difficulties. The study shows that the policy documents advocate inclusion while at the same time legitimising vocational special school solutions. Finally, the study identifies and problematises the discursive meanings of the concept of 'inclusion' and different categorisations of the concept 'special'.

\section{School organisation and its implementation}

In a number of extensive questionnaire studies on the Swedish upper secondary school, Ramberg $(2013,2015,2017)$ presents an analysis of the availability of special education resources and the use of ability grouping, as well as of in what subjects, and where, special needs education is conducted. For example, the results show that independent schools offer fewer special needs resources than municipal schools and that ability grouping is used more often in foundation courses than in programme-specific courses. It is also shown that special needs education mainly takes place outside the regular classroom, and that special needs resources are primarily allocated to the subjects of Mathematics, English and Swedish. Taken together, Ramberg's studies indicate that SNE in VET is not prevalent in Swedish upper secondary schools.

\section{Discussion}

The purpose of this review was to describe and analyse Nordic research on special needs education (SNE) in the context of the Nordic countries' vocational education and training (VET) systems published between January 2010 and September 2018. The results show that there are relatively few studies on SNE-VET, and that most are focused on the practice level. How this can be explained and understood is discussed in this section.

While our review of the Nordic countries' VET systems reveals the differences between the countries' vocational education systems, it is not differences or similarities between these systems that are the most interesting but the frequent changes made to these systems. These constant educational reforms show a strong political interest in vocational education, which has not always benefitted the development of VET (Helms Jørgensen, 2018).

When a field of study is frequently changed, there is a risk that the research focus will also shift, in this case from the educational opportunities of all students and SNE to the actual changes in the content of VET, or how new VET reforms are implemented. We did find studies on VET policy, but the lack of an SNE focus in these studies meant that they could not be included in the review. The scarcity of policy studies within the field of SNE/VET may in turn result in few studies at the organisation and practice level. This may be one reason why our review of 
Nordic VET research reveals that SNE is an almost invisible research area, as shown by the fact that we found relatively few research articles that matched our search criteria.

Another reason why SNE in VET is a weak field of research might be that many vocational programmes have traditionally been limited to crafts, the learning of which did not require SNE support. The fact that the practice level dominates in our review is not surprising, as VET institutions usually have diverse student populations with sometimes challenging educational needs.

Most of the included studies belong to the practice level. The most frequent identified themes were teachers' work and role (7 studies) and students with special educational needs - transition (5 studies). Only one study dealt with teaching and learning. The focus in the practice level studies seems to be on teachers and students, while studies explicitly focusing on teaching arrangements for students with SEN are almost non-existent. This was a bit surprising, keeping in mind that students' challenges often require special educational support strategies on school and classroom level. In addition to practice level studies, we found SNE research at the organisation level (5 studies). These studies focus on national goals, implementation of SNE and resource use. These findings were expected since resources and structural factors relate to educational practices.

Although VET studies at the policy level are available, especially in Sweden, our findings show that policy studies with an SNE focus are almost non-existent. The lack of policy level studies reflects the overall scarcity of studies on SNE in Nordic VET. In view of the increasing focus on inclusive education at all levels of the Nordic education systems, we find this result somewhat surprising. For this reason, we believe it is important to increase the knowledge of SNE among VET researchers, as this would probably result in more policy level studies, which is an important prerequisite for developing Nordic VET in an inclusive direction.

Although it might be argued that our search criteria were quite strict, the results are evident. A mere 20 studies during a nine-year period (2010-2018) addressed SNE from an organisation or practice perspective.

When we look at the number of studies across the Nordic countries, a clear pattern emerges. Finland dominates in terms of number of research articles. More than half $(13 / 20)$ of the studies were performed by Finnish researchers. We found a few studies by Swedish, Norwegian and Icelandic researchers but no Danish ones. On the basis of our empirical data, it is not possible to identify the reason for the uneven distribution of research articles on SNE among the countries concerned. However, one plausible reason might be the relatively strong position of SNE in Finnish VET. The focus on SNE in Finnish VET is due to historical as well as educational traditions, but also to the fact that, in Finland, SNE is an independent scientific discipline. This is not the case in the other Nordic countries. For instance, Finland is the only Nordic country to have a university or polytechnic- 
based education for vocational special education teachers aimed at providing the teacher students with a thorough knowledge of SNE for the VET sector. In addition, the regular vocational teacher education includes elements of SNE. Finnish policy documents guiding VET also acknowledge SNE as a support system for all students who need special educational support. Unlike the other Nordic countries, Finland also has a low-threshold support system.

The limitations of this study are mainly of a methodological nature. It is a major challenge for authors of a literature review to find all the research done in the field under study. We have tried to come to terms with this problem by using an extremely meticulous search procedure. For example, we conducted repeated searches in Nordic and international research databases and supplemented these with additional searches in a selection of SNE and VET journals. The challenges involving inclusion or exclusion of studies have been another major concern. Initially, we located 42 studies that seemed to belong to our area of interest but on closer examination, 22 of these did not meet our selection criteria. For example, studies focusing on dropout from education, but lacking a clear focus on SNE were excluded. Keeping in mind the difficulty of clearly defining the field of SNE, our strict selection criteria led to exclusion of certain articles, which could have broadened the scope of SNE in VET.

\section{Further research}

Our results show that there are many areas for further research. The present study points to a lack of research on the policy level. We find the topic interesting and one area for further research might be a review of the Nordic countries' reforms in VET and the implications for SNE. Other possible research areas might be VET teachers' knowledge of SEN and SNE and their descriptions of how they implement this knowledge in the classroom, and what kind of support VET students receive in the school practice. Comparative studies on SNE in VET might contribute to the development of VET in the Nordic countries.

\section{Notes on contributors}

Camilla Björk-Åman works as university teacher at Åbo Akademi Unversity, Faculty of Education and Welfare Studies, and as associate professor at Nord University. Camilla's fields of research are inclusive education, roles and work of special education teachers, and counselling for VET-students with SEN.

Robert Holmgren is senior lecturer at Umeå University, Department of Education. His main research interests are ICT and learning, and teaching and learning in vocational education and training. 
Gerd Pettersson is senior lecturer at Umeå University, Department of Education. Gerd's fields of research are special education profession, inclusive education and teaching and learning in vocational education and training.

Kristina Ström is professor of special education at Åbo Akademi University, Faculty of Education and Welfare Studies. Her main research interests are inclusive education, comparative perspectives on special education and special education profession. 


\section{References}

Act relating to primary and secondary education and training (Education act). (1998). Lov om grunnskolen og den vidaregåande opplxinga (Opplæringslova). Kunnskapsdepartementet. https://lovdata.no/dokument/NL/lov/1998-0717-61

Ahlberg, A. (2009). Kunskapsbildning i specialpedagogik [Knowledge of special education]. In A. Ahlberg (Ed.), Specialpedagogisk forskning: En mångfacetterad utmaning [Special education research: A multifaceted challenge] (pp. 9-28). Studentlitteratur.

Bell, S., Hirvonen, M., Kukemelk, H., Pancocha, K., Vadurova, H., \& Hion, P. (2014). The inclusion of students with special educational needs in vocational education and training: A comparative study of the changing role of SEN teachers in the European context (Finland, England, the Czech Republic and Estonia). Socialiniai Tyrimai [Social Research], 35(2), 42-52.

Björk-Åman, C. (2013). Extremfall, stjärnelever och verktygsskramlare: En diskursanalytisk studie av lärares tal om studerande som behöver särskilt stöd [Extremcases, starpupils and toolrattlers: A discourse analytical study of teachers' talk about special needs students]. (PhD dissertation). Åbo Akademis förlag. https://www.doria.fi/bitstream/handle/10024/93418/bjork_camilla.pdf?sequence $=2$

Cedefop. (2010). Employer-provided vocational training in Europe: Evaluation and Interpretation of the third continuing vocational training survey. Publications Office of the European Union.

Cedefop. (2015). Skills, qualifications and jobs in the EU: The making of a perfect match? (Cedefop Reference Series No. 103). Office for the Official Publications of the European Union. http://www.cedefop.europa.eu/en/publicationsand-resources/publications/3072

Cedefop Dk. (2012). Vocational education and training in Denmark: Short description. European Centre for the Development of Vocational Training. Publications Office of the European Union. http://www.cedefop.europa.eu/EN/Files/4112_en.pdf

Danish Evaluation Institute. (2019). Elever, der modtager specialpædagogisk støtte, klarer sig ganske godt [Students who receive special educational support do quite well]. Danmarks Evalueringsinstitut.

https://www.eva.dk/ungdomsuddannelse/elever-modtager-specialpaedagogisk-stoette-klarer-sig-ganske-godt

Decree on teacher qualifications. (1998/2017). Förordning om behörighetsvillkoren för personal inom undervisningsväsendet. Undervisningsministeriet. https://www.finlex.fi/sv/laki/ajantasa/1998/19980986 
Eiriksdottir, E., \& Rosvall, P.- $\AA$. (2019). VET teachers' interpretations of individualisation and teaching of skills and social order in two Nordic countries. European Educational Research Journal, 18(3), 355-375.

Finnish National Agency for Education. (2018a). Oppilas-/opiskelijamääräraportit syksyllä 2017 [Reports on the amount of students, autumn 2017]. https://vos.oph.fi/rap/ptr/s17/ptrrap.html

Finnish National Agency for Education. (2018b). Lägesöversikt, andra stadiet. [Situation overview, second stage].

https://www.oph.fi/lagesoversikt/andra_stadiet/genomstromning

Finnish Vocational Education and Training Act. (2017). Lag om yrkesutbildning (531/2017). Undervisnings- och kulturministeriet. https:// www.finlex.fi/sv/laki/alkup/2017/20170531

Fischbein, S., \& Österberg, O. (2003). Mötet med alla barn: Ett specialpedagogiskt perspektiv [The meeting with all children: A special education perspective]. Gothia.

Foreldreutvalget for grunnopplæringen. (2018). Spesialundervisning/IOP [Special needs education].

https:/ / www.fug.no/spesialundervisning-iop.475740.no.html

Government of Iceland. (2019). Education. http://www.government.is/topics/education/

Graneheim, U. H., \& Lundman, B. (2004). Quality content analysis in nursing research: Concepts, procedures and measures to achieve trustworthiness. Nurse Education Today, 24, 105-112.

Hakala, K. (2010). Discourses on inclusion, citizenship and categorizations of 'special' in education policy: The case of negotiating change in the governing of vocational special needs education in Finland. European Educational Research Journal, 9(2), 269-283.

Hakkarainen, A., Holopainen, L., \& Savolainen, H. (2013). Mathematical and reading difficulties as predictors of school achievement and transition to secondary education. Scandinavian Journal of Educational Research, 57(5), 488-506.

Helms Jørgensen, C. (2018). Vocational education and training in the Nordic countries: different systems and common challenges. In C. H. Jørgensen, O. J. Olsen, \& D. P. Thunqvist (Eds.) (2018). Vocational education in the Nordic countries: Learning from diversity. Routledge. https://www.routledge.com/Vocational-Education-in-the-Nordic-Countries-Learning-from-Diversity/Jorgensen-Olsen-Thunqvist/p/book/9781138219809

Helms Jørgensen, C., Lundahl, L., \& Järvinen, T. (2019). A Nordic transition regime? Policies for school-to-work transitions in Sweden, Denmark and Finland. European Educational Research Journal, 18(3), 278-297.

https:/ / doi.org/10.1177/1474904119830037 
Hermanoff, A., Määttä, K., \& Uusiautti, S. (2017). The opportunities and obstacles of school paths of Finnish young people with intellectual disability (ID). Problems of Education in the 21st Century, 75(1), 19-33.

Hirvonen, M. (2011). From vocational training to open learning environments: Vocational special needs education during change. Journal of Research in Special Educational Needs, 11(2), 141-148.

Hirvonen, M. (2012). Towards inclusion? Vocational special needs education from a historical perspective. In S. Stolz, \& P. Gonon (Eds.), Challenges and reforms in vocational education: Aspects of inclusion and exclusion (Studies in vocational and continuing education, Vol. 11, pp. 165-178). Peter Lang.

Hirvonen M. (Ed.). (2015a). Suunnitellen ja koordinoiden: Kohti kaikille yhteistä ammatillista oppilaitosta [Planning and coordinating: Towards a vocational education institution for all]. Jyväskylän ammattikorkeakoulu.

Hirvonen M. (Ed.). (2015b). Yhdessä toimien ja erilaisuutta arvostaen: Ammatilliset opettajakorkeakoulut erityisopetusta kehittämässä [Collaborating and celebrating diversity: Schools of professional teacher education developing special education]. Jyväskylän ammattikorkeakoulu.

Hirvonen M. (Ed.). (2018). Hei me HOKSataan! Ammatillisten opettajakorkeakoulujen puheenvuoro erityisten tuen tilasta ja kehittämisestä [Hello we individualise! Comment from Jyväskylä School of Professional Teacher Education on the state and development of special support] (Jyväskylän ammattikorkeakoulun julkaisuja 252). Jyväskylän ammattikorkeakoulu.

Hirvonen, M., Ladonlahti, T., \& Pirttimaa, R. (2009). Ammatillisesta erityisopetuksesta tuettuun ammattiin opiskeluun: Näkökulmia ammatillisen erityisopetuksen ja koulutuksen kehittämiseen [From vocational special training to supported vocational studies: Perspectives on the development of vocational special needs education]. Kasvatus, 40(2), 158-167.

Kirjavainen, T., Pulkkinen, J., \& Jahnukainen, M. (2016). Special education students in transition to further education: A four-year register-based follow-up study in Finland. Learning and Individual Differences, 45, 33-42.

Kiuppis, F., \& Sarromaa Hausstätter, R. (2014). Inclusive education: Twenty years after Salamanca. Peter Lang.

Kvalsund, R., \& Bele, I. V. (2010). Students with special educational needs: Social inclusion or marginalisation? Factors of risk and resilience in the transition between school and early adult life. Scandinavian Journal of Educational Research, 54(1), 15-35.

Lundahl, L. (2016). Equality, inclusion and marketization of Nordic education: Introductory notes. Research in Comparative and International Education, 11(1), 3-12.

Michelsen, S., \& Stenström, M. L. (Eds.). (2018). Vocational education in the Nordic countries: The historical evolution. Routledge. 
Ministry of Children and Education, Denmark. (2010). Statistik om erhvervsuddannelserne [Statistics on vocational education]. https://www.uvm.dk/statistik/erhvervsuddannelserne

Ministry of Children and Education, Denmark. (2019a). Klare mål 2: Flere skal gennemføre [Clear goal 2: More vocational students must complete]. https:/ / www.uvm.dk/statistik/erhvervsuddannelserne/klare-maal-foreud-reformen/klare-maal-2-flere-skal-gennemfoere

Ministry of Children and Education, Denmark. (2019b). Ungdomsuddannelser til en elev med en funktionsnedsættelse [Youth education for a student with a disability]. https://www.spsu.dk/for-sps-ansvarlige/ungdomsuddannelser/ungdomsuddannelser-med-sps

Ministry of Children and Education, Denmark. (2019c). Bekendtgørelse af lov om erhvervsuddannelser [Vocational education act]. (LBK nr 957 af 17/09/2019). https:/ / www.retsinformation.dk/Forms/R0710.aspx?id=210275

Ministry of Education and Culture \& Finnish National Agency for Education. (2018). Finnish VET in a nutshell. https:/ / www.oph.fi/sites/default/files/documents/finnish_vet_in_a_nutshell.pdf

Ministry of Education, Science and Culture, Iceland. (2011). The national curriculum guide for upper secondary schools: General section. https://www.stjornarradid.is/verkefni/menntamal/namskrar/\#Tab1

Myklebust, J. O. (2013). Disability and adult life: Dependence on social security among former students with special educational needs in their late twenties. British Journal of Special Education, 40(1), 5-13.

Námsmatsstofnun. (2014). Brotthvarf úr framhaldsskólum [Drop-outs from upper secondary education]. https://www.stjornarradid.is/media/menntamalaraduneyti-media/media/frettir2014/brotthvarsskyrsla-haust-2014.pdf

Niemi, A., \& Kurki, T. (2014). Getting on the right track? Educational choice-making of students with special educational needs in pre-vocational education and training. Disability \& Society, 29(10), 1631-1644.

Norwegian Ministry of Education and Research. (2011). Learning together: Meld. St. 18 (2010-2011) Report to the Storting (white paper) Summary. https:/ / www.regjeringen.no/contentassets/baeeee60df7c4637a72fec2a18273d8b/en$\mathrm{gb} / \mathrm{pdfs} /$ stm201020110018000en_pdfs.pdf

Opetushallitus. (2018). Erityinen tuki ammatillisessa koulutuksessa [Intensive special support in vocational education and training]. https://eperusteet.opintopolku.fi/eperusteet-service/ api/dokumentit/4637898

Pereira, E., Kyriazopoulou, M., \& Weber, H. (2016). Inclusive vocational education and training (VET): Policy and practice. In A. Watkins, \& C. Meijer (Eds.), Implementing inclusive education: Issues in bridging the policy-practice gap (International Perspectives on Inclusive Education, Vol. 8, pp. 89-107). Emerald. 
Pettersson, G. (2017). Inre kraft och yttre tryck: Perspektiv på specialpedagogisk verksamhet $i$ glesbygdsskolor [Inner power and outer pressure: Perspectives on special needs education in rural schools]. (PhD dissertation). Umeå universitet.

Pirttimaa, R., \& Hirvonen, M. (2016). From special tasks to extensive roles: The changing face of special needs teachers in Finnish vocational further education. Journal of Research in Special Educational Needs, 16(4), 234-242.

Pijl, S. J., Frostad, P., \& Mjaavatn, P. E. (2014). Students with special educational needs in secondary education: Are they intending to learn or to leave? European Journal of Special Needs Education, 29(1), 16-28.

Ramberg, J. (2013). Special educational resources in the Swedish upper secondary schools: A total population survey. European Journal of Special Needs Education $28(4), 440-462$.

Ramberg, J. (2016). The extent of ability grouping in Swedish upper secondary schools: A national survey. International Journal of Inclusive Education 20(7), 685-710.

Ramberg, J. (2017). Focus on special educational support in Swedish high schools: Provision within or outside the students' regular classes? In S. Bagga-Gupta (Ed.), Marginalization processes across different settings: Going beyond the mainstream (pp. 44-80). Cambridge Scholars Publishing.

Swedish education act. (2010:800). Skollagen. Swedish Ministry of Education. https:/ / www.riksdagen.se/sv/dokument-lagar/dokument/svensk-forfattningssamling/skollag-2010800_sfs-2010-800

Swedish National Agency for Education. (2011). Läroplan för gymnasieskolan [National Curriculum for upper secondary school]. https://www.skolverket.se/undervisning/gymnasieskolan/laroplan-program-och-amnen-i-gymnasieskolan/laroplan-gy11-for-gymnasieskolan

Swedish National Agency for Education. (2014). Allmänna råd om arbete med extra anpassningar, särskilt stöd och åtgärdsprogram [General advice on work with extra adaptations, special support and action programs]. https://www.skolverket.se/regler-och-ansvar/ansvar-i-skolfragor/extra-anpassningar-och-sarskilt-stod-i-skolan

Swedish National Agency for Education. (2018). Gymnasieskolan: Personalstatistik [Upper secondary school: Personnel statistics]. https://siris.skolverket.se/reports $/$ rwservlet?cmdkey $=$ common\&geo $=1 \&$ report $=$ gy_personal\&p_sub=1\&p_flik=G\&p_ar=2018\&p_lankod=\&p_kommunkod=\&p_skolkod=\&p_hmantyp $=\& p \_h m a n k o d$

Statistics Iceland. (2016). Talnaefni: Framhaldsskólastig [Statistics: Upper secondary level]. Hagstofa Íslands.

Statistics Norway. (2018). Upper secondary education. https:/ / www.ssb.no/en/utdanning/statistikker/vgu/aar 
Stefánsdóttir, G. V., \& Björnsdóttir, K. (2016). 'I am a college student' postsecondary education for students with intellectual disabilities. Scandinavian Journal of Disability Research, 18(4), 328-342.

Studyinfo. (2019). Fields of vocational education and training. https://studyinfo.fi/wp2/en/vocational-education-and-training/fields-of-vocational- education -and-training/

Tangen, R. (2012). Hva er spesialpedagogikkens mål og oppgaver [What are the goals and tasks of special education]. In E. Befring, \& R. Tangen (Eds.), Spesialpedagogikk [Special education] (pp. 17-30). Cappelen Akademisk Förlag. Upper secondary education act. (2008). Ministry of Education, Science and Culture. https:/ / www.government.is/media/menntamalaraduneyti -media/media/law-and-regulations/Upper-Secondary-Education-Act-No.-92-2008.pdf

Utdanningsdirektoratet. (2017). Ordförklaring och roller: Spesialundervisning [Glossary and roles: Special education]. https://www.udir.no/laring-og-trivsel/sarskilte-behov/spesialundervisning /ordforklaring-og-roller-spesialundervisning/

Utdanningsdirektoratet. (2018). Gjennomføring $i$ videregående opplæring [Completion in upper secondary education]. https://www.udir.no/tall-ogforskning/finn-forskning/tema/gjennomforing2/gjennomforing-i-videregaende2/

Vilbli.no. (2019). Upper secondary education. https:/ / www.vilbli.no/nb/en/no 


\section{Appendix 1}

SEN and VET journals included in the search process:

SEN journals

British Journal of Special Education

Exceptional children

European Journal of Special Needs Education

Journal of Research in Special Educational Needs

Journal of Special Education

Journal of Special Education Technology

Scandinavian Journal of Disability Research

Support for Learning

\section{VET journals}

Education + Training

Empirical Research in Vocational Education and Training

International Journal of Research in Vocational Education and Training

International Journal of Training Research

Journal of Vocational Education and Training

Nordic Journal of Vocational Education and Training

Skandinavisk tidskrift for yrker og profesjoner i utvikling

Vocations and Learning 